\title{
Electronic parts selection during the product development process in Brazilian companies
}

\author{
Rafael Perez Pagan ${ }^{a}$, Carlos Eduardo Sanches da Silva ${ }^{a}$, Lucas Catalani Gabriel, Eduardo Gomes Salgado \\ Instituto de Engenharia de Produção e Gestão, Universidade Federal de Itajubá - UNIFEI \\ UUniversidade Federal de Alfenas - UNIFAL-MG \\ e-mails: ra.pagan@gmail.com; sanches@unifei.edu.br; lucas.catalani@unifei.edu.br; eduardosalgado@unifal-mg.edu.br
}

\begin{abstract}
Electronic products are composed of a dependent and interconnected set of parts that carry out the product's internal functions. Consequently, parts selection is crucial for developers. Companies must keep abreast of the new technologies launches during that activity. However, the lack of parts manufacturers in Brazil can prevent access to these launches. The aim of this study is to analyze criteria used by Brazilian companies during the selection of electronic parts in the Product Development Process (PDP), identifying characteristics that influence the selection of components and the major motivators for changes in a product's bill of materials after its launch. A descriptive survey was used for this purpose. The system and the data collection instrument proposed were validated through pilot testing and applied to a random sample of 75 Brazilian companies that develop electronic products. The results show the importance of selection criteria that consider the product environment, attributing parts qualification activities to the manufacturers and distributors. The criteria are even more important when considering parts with higher added value because of the risk of redesign involved in the process. Moreover, the study shows that the greatest motivator for changes in the bill of materials is in part obsolescence.
\end{abstract}

Keywords: parts selection, life cycle environmental profile, component qualification, product development process.

\section{Introduction}

Electronics have been one of the main foundations for innovation in many industries. Products dedicated to biomedicine, automation, and intelligent energy systems as well as traditional consumer goods such as laptop computers, tablets, and smartphones are pushed forward by constant technological advances in the miniaturization of electronic components and by more rigorous requirements of the market (KIM, 2012; SHIPP et al., 2012; LEAHY; OSTER, 2012).

According to Mallick \& Schroeder (MALLICK; SCHROEDER, 2005) the commercial success of a new electronic component is directly related to low cost and development time. These products have a greater chance of success if they are cheaper and get onto the market early (LAU, 2002; CORCORAN, 2012). Therefore, the product development process (PDP) becomes relevant as a means of assuring the survival and growth of companies in the electronics industry.

There are factors that differentiate the PDP of this sector from others. Tripathy and Eppinger (2011) reported that the development of electronic products is complex because they involve a large number of interconnected and dependent components. Moulianitis et al. (2004), point out that many possible solutions exist for the same electronic function of a product. This makes later rework or changes more difficult. Foucher et al. (1998) and Helo (2004) argue that, unlike in other industries, the era of verticalization is considered obsolete and uneconomical in the electronics industry. Each company in the industry concentrates on its core business. This idea is supported by Minderhoud and Fraser (2005) and Eppinger and Chitkara (2009), who treat the development of electronic products as a global process in which different activities are carried out in different places depending on their specialty.

Successful electronics developers do not wait for internal technological advances; they must pay attention to the roadmaps of other companies in the industry, especially companies that produce manufacture electronic components (HELO, 2004; GRIFFIN et al., 2009). This situation requires companies to develop methods for selecting electronic components, such as those described in IEC/TS 62239 and ANSI/EIA 4899 (SYRUS; PECHT; HUMPHREY, 2001). However, Jackson et al. (1999) and Pecht (2004) state that these guidelines are insufficient to guarantee the correct choice of components for a product. 
During the PDP, the time of components choice can have an impact on cost and product development time. At the beginning of PDP, decisions are less costly and benefits can be greater, but there is more uncertainty, and therefore an error during component selection can cause drastic changes in the following phases. During later phases, the uncertainty is reduced in the decisions, but there is less chance of lowering costs, thus restricting the options for components to those with specifications that were determined in earlier phases (KRISHNAN; ULRICH, 2001; MILLSON; WILEMON, 2006; REDDI; MOON, 2011).

In Brazil, other factor increases the difficulty of component selection: there is little electronic component manufacturing inside the country (ASSOCIAÇÃO..., 2010; BANCO..., 2010). Thus, Brazilian developers depend on foreign technology and have a limited access to information. In an industry where component selection and information exchange between participants are crucial, these characteristics can interfere with the success of a product. Therefore, the research question is: how Brazilian companies select the electronic parts of their products?

The general aim of this study is to analyze the criteria used when selecting electronic components during PDP in Brazilian electronics companies. This can be divided into five specific objectives:

- Evaluate which selection criteria are more or less relevant;

- Analyze how the situation and characteristics of companies in Brazil influence component selection;

- Identify if there are important differences caused by different types of criteria and components;

- Analyze the motivators for changes in the bill of materials (BOM);

- The correlation between these changes and the way the components are selected.

To carry out these objectives, a conceptual model was created using hypotheses related to the constructs that make up the description of the organization, the evaluation of component selection criteria, and changes in the BOM after product launch. Afterwards, a descriptive survey was carried out in 75 Brazilian electronics companies in order to describe the constructs and test the hypotheses of the model proposed for the research population.

\section{Theoretical background and hypothesis}

\subsection{Selection of electronic components during PDP}

The moment when the product development team starts to select the components used in the product differs among the reference models in the literature. Minderhoud and Fraser (2005) and McIvor et al. (2006) suggest that components with high added value must be selected in the initial phase of PDP, while components with low added value can be chosen in later phases. Haskell (2004) states that more expensive components should be selected by the development team in the beginning of the process, and the products with little added value can be defined by the purchasing team.

Hunt and Jones (1998) place component selection at the beginning of PDP, pointing out that the components, never been utilized by the organization, should be treated more carefully. According to Gausemeier et al. (2011), the people who select components and those responsible for assembly and production of the product should communicate with each other. It is also suggested that it is a good practice for the supplier to be involved in component selection, if it is correctly executed (MILLSON; WILEMON, 2006; YANG et al., 2011).

Despite the characteristics listed above, reference models for PDP in electronics do not bring a lot of emphasis on component selection. Some authors do not even talk about the activity. What can be noticed is a classification of components at the moment they are chosen between high and low added value. The first two hypotheses of the study investigate this difference:

$\mathbf{H}_{1 \mathbf{A}}$ : The importance of the evaluation criteria for selecting components with high and low added values is different.

$\mathbf{H}_{1 \mathbf{B}}$ : There is a positive correlation between the importance of evaluation criteria for selecting components with high and low added values.

\subsection{Selection criteria for electronic components}

The need for a selection and management method for electronic components is not new in the industry. In the 1950s, the American Department of Defense (DoD) began to apply the first guidelines in order to reduce uncertainty resulting from the selection of electronic components. As time passed, many of these guidelines have come to be used by civilian organizations as well. However, beginning in the 1980s, with the advance of the proportion of electronic products in industries such as automotive, manufacturing, telecommunications, and consumer goods, new guidelines were developed to help private organizations to be more flexible and agile with technological advances (FOUCHER, et al., 1998; SYRUS; PECHT; HUMPHREY, 2001).

Today, some guidelines stand out for management and selection of electronic components. ANSI EIA 4899 and IEC/TS 62239 were published by different organizations but have the same objective: to define the requirements 
for developing an Electronic Component Management Plan (ECMP) to assure clients and licensing agencies that all of the electronic components in products are selected using an evaluation with a set of specific criteria (INTERNATIONAL..., 2008). In the military arena, guideline MIL-STD-3018 (with change-2) stands out. This suggests that companies developing products for military use implement a Parts Management Program (PMP). PMP is defined as the practice of analyzing the application, standardization, technology, reliability, maintenance, support, cost, availability, logistics support, and legal questions in choosing components in order to support the company and the life cycle of its products (DEPARTMENT..., 2015; DEFENSE..., 2013).

In the literature, the method that emerge the most is the first one proposed by Jackson et al. (1999) and later developed by Pecht (2004). This method consists of a process that evaluates each component on the BOM from its selection to post-launch follow-up. It is based on a series of evaluation criteria (JACKSON et al., 1999; PECHT, 2004).

The guidelines ANSI EIA 4899, IEC TS 62239, and MIL-STD-3018 and the method proposed by Jackson et al. (1999) and Pecht (2004) list criteria for selecting electronic components. Table 1 describes the most relevant criteria divided into two groups called component and application.

component group is comprised of the component evaluation criteria without taking the LCEP into consideration. It is an evaluation of the component itself. The application group is constituted by the evaluation criteria considered in the LCEP. It is an evaluation of the component in the context of the product and the company. This leads to the following two hypotheses:
$\mathbf{H}_{2 \mathrm{~A}}$ : The importance of the selection criteria of the application group and component group are different.

$\mathbf{H}_{2 \mathrm{~B}}$ : The importance of the selection criteria of the application group is positively correlated with the importance of the selection criteria of the component group.

\subsection{Changes in the BOM}

The level of importance during evaluation of selection criteria of a component can influence whether it remains on the BOM of the product even after it enters the market (PECHT, 2004). Some reasons that can lead to changes of the BOM connected to the selection criteria of the component group can be cited:

- Organizations that do not evaluate whether their manufacturers or suppliers are a good source of information can undergo product alterations or obsolescence without warning (SHUNK et al., 2007; MURRAY et al., 2002).

- Ignoring the tracking procedure, the capability of manufacturers or suppliers of a component can lead to acquiring counterfeit components. In this case, the component can have a shorter life cycle and presents a greater risk of non-compliance (CHATTERJEE; DAS, 2007; SOOD; DAS; PECHT, 2011).

- Product failure, especially during the initial phase of the life cycle, can be caused by choosing components that do not work in the way explained

Table 1. Selection criteria for electronics components.

\begin{tabular}{|c|c|c|}
\hline Group & Criteria & Description \\
\hline \multirow{4}{*}{ Component } & Manufacturer & $\begin{array}{l}\text { Verify that the component manufacturer has: process control; storage, handling, and transport control; } \\
\text { corrective and preventive action procedures; ability to track the component; and notification procedures } \\
\text { for alterations in the component. }\end{array}$ \\
\hline & Distributor & $\begin{array}{l}\text { Verify that the component distributer has: delivery service quality control; process control; storage, } \\
\text { handling, and transport control; corrective and preventive action procedures; ability to track the } \\
\text { component; and customer support service. }\end{array}$ \\
\hline & Family & $\begin{array}{l}\text { Verify that the product line the component belongs to has continuous documented measurement of } \\
\text { the capability index and the number of nonconformities in the production process, as well as carrying } \\
\text { out periodic tests of the monitoring. }\end{array}$ \\
\hline & Information access & $\begin{array}{l}\text { Verify the accessibility of information of the component, such as: datasheets; errata sheets; technical } \\
\text { documents; applications documents; assembly instructions; obsolescence or change warning; } \\
\text { qualification data; and manufacturing data. }\end{array}$ \\
\hline \multirow{4}{*}{ Application } & Performance & $\begin{array}{l}\text { Verify that the component: performs the desired internal function for the product; is electromagnetically, } \\
\text { thermally, and mechanically compatible. }\end{array}$ \\
\hline & Reliability & $\begin{array}{l}\text { Verify that monitoring and qualification tests are able to be maintained throughout the planned } \\
\text { lifecycle of the product. }\end{array}$ \\
\hline & Assembly & $\begin{array}{l}\text { Verify that the component: is compatible with the planned assembly methods for the product; has the } \\
\text { connections designed for the product; can be tested and maintained within the product. }\end{array}$ \\
\hline & Obsolescence & Verify that the life cycle of the component is compatible with the life cycle of the product. \\
\hline
\end{tabular}


on their datasheets due to lack or poor quality in their process, transport, and handling control by their manufacturers or suppliers (YANG et al., 2011; GOEL; GRAVES, 2006; CHALLA; RUNDLE; PECHT, 2013).

For the application group, other reasons that lead to BOM changes can be cited:

- Incompatibility of the manufacturing process can affect the economic viability and performance of the project (ASHMORE, 2007; KHAN, 2008; YI et al., 2012);

- Lack of synchronization between the life cycle of the component and the life cycle of the product can make the product obsolete before the end of its life cycle (BRADLEY; GUERRERO, 2008; ROJO; ROY; SHEHAB, 2010; SANDBORN; PRABHAKAR; AHMAD, 2011);

- The selection of a component with maximum or recommended parameters that do not correspond with the reality of LCEP can lead the product to not work properly in the field or the product's early failure (DAS et al., 2000; YANG; BERNSTEIN, 2009).

The next five hypotheses of the study are defined here:

$\mathbf{H}_{3}$ : The importance of the selection criteria is positively correlated with the time between product launch and the need to change the BOM.

$\mathbf{H}_{4}$ : The importance of the selection criteria of the component group is negatively correlated with the frequency of problems it experiences.

$\mathbf{H}_{5}$ : The importance of the selection criteria of the application group is negatively correlated with the frequency of problems it experiences.

$\mathbf{H}_{6}$ : The importance of selection criteria for components with low added value is negatively correlated with the frequency of problems with the component.

$\mathbf{H}_{7}$ : The importance of selection criteria for components with high added value is negatively correlated with the frequency of problems with the component.

At the same time, in order to understand how the causes of changes in BOM not considering the importance of the criteria are distributed, the following hypotheses are proposed:

$\mathbf{H}_{\mathbf{8} \mathbf{A}}$ : The frequencies of changes in the BOM caused by problems related to the component group and the application group are different.
$\mathbf{H}_{\mathbf{8 B}}$ : There is a positive correlation between problems related to the component group and the application group.

$\mathbf{H}_{9 \mathrm{~A}}$ : The frequencies of changes of the BOM are different between components with high and low added values.

$\mathbf{H}_{9 \mathbf{B}}$ : There is a positive correlation between the frequencies of problems with components of high and low added values.

\subsection{Characteristics of Brazilian companies}

The characteristics of the company can also influence the importance of the selection criteria. The differences between decisions made by companies of different sizes are analyzed in various studies (LEDWITH, 2000; GUTIERREZ; OROZCO; SERRANO, 2009; JABBOUR, et al., 2011). The age of the company has also been demonstrated to be a criterion that differentiates one company from another (LI; LIU; LIU, 2011; NORDIN; DEROS; WAHAB, 2011; IYER; SARANGA; SESHADRI, 2013).

The situation in Brazil has other factors that can influence the evaluation of selection criteria. According to the Brazilian Development Bank (BNDES) and the Brazilian Electronics Association (ABINEE), the greatest challenge for Brazilian companies that develop electronic products is a result of the low number of component manufacturers in the country (ASSOCIAÇÃO..., 2010; BANCO..., 2010).

The companies in the electronics complex that have the majority of the market share in Brazil are large multinational corporations. Their activities basically consist in assembling kits of imported components (BANCO..., 2010). Hauser et al. (2007) points out that as a consequence of this situation, project engineering and component selection take place in their home countries, increasing the technological dependence of Brazil in the industry.

Another important point is the risk of counterfeit components. According to Livingston (2007), companies that buy electronic components manufactured in developing economies are more vulnerable to this type of risk. The main reason is that in many of these countries, the growth of the infrastructure and development for the production of components has not been met with anti-counterfeiting policies. Pecht and Tiku (2006) mention that China is one of the countries where this practice is the most common. Today, almost $70 \%$ of the electronic components imported by Brazil come from developing countries, mainly China and other Asian countries (ASSOCIAÇÃO..., 2013). Therefore, the care that must be taken to avoid acquisitions of counterfeit electronic components should be considered a critical factor in Brazilian companies. 
In order to understand how these variables influence the evaluation of the selection criteria of the components, the last three hypotheses of the study are:

$\mathbf{H}_{10}$ : The influence of critical factors in Brazil to the organization is positively correlated with the importance of the selection criteria.

$\mathbf{H}_{11}$ : The importance of selection criteria differs depending on the size of the company.

$\mathbf{H}_{12}$ : The importance of selection criteria is positively correlated to the age of the company.

A final diagram of the theoretical model proposed for the study is shown in Figure 1.

\section{Methodology}

\subsection{Classification of the method}

This study does not seek to test the causal relationship between the constructs, which means testing the hypotheses stating that one event leads to another through a temporal sequence. For this reason, the method utilized was limited to describing the distribution of the phenomena and testing possible relationships that represent a trend or standard among the constructs and not causality. This characteristic of relationships can influence the classification of the study. According to Malhotra and Grover (1998) and Forza (2002), this study should be classified as a descriptive survey. Rungtusanathan et al. (2003) would classify the study as descriptive and rational. The present study uses the transversal descriptive survey method.

\subsection{Population and sampling}

The target population of this study is Brazilian companies developing products that use printed circuit boards (PCBs). An initial list of 872 companies that are part of the main associations and syndicates in the Brazilian electronics industry according to the National Industrial Confederation (CNI) (CONFEDERAÇÃO..., 2017). Then, an analysis was carried out company by company with the objective of eliminating problems with out-of-date information, repetitions, and poorly identified companies in the population. After the analysis, 230 companies were eliminated because the information was out of date, repeated or were identified incorrectly as being part of the electronics industry. 141 companies were eliminated because they were not Brazilian, other 127 because they do not develop their own products and 119 were eliminated because they did not use printed circuit boards. Finally, a list of 255 companies formed the final population that this study represented in the results and conclusions.

Since the goal was not to distribute the constructs by state or agency, the population of 255 companies was considered to be homogeneous in regard for the constructs and hypotheses of the study. For this purpose, a simple random sample method was chosen; that is, all of the companies in the population had the same chance to participate in the sample. In order to calculate the sample size, the following conditions were stipulated: a significance level of $\alpha=0.05$;

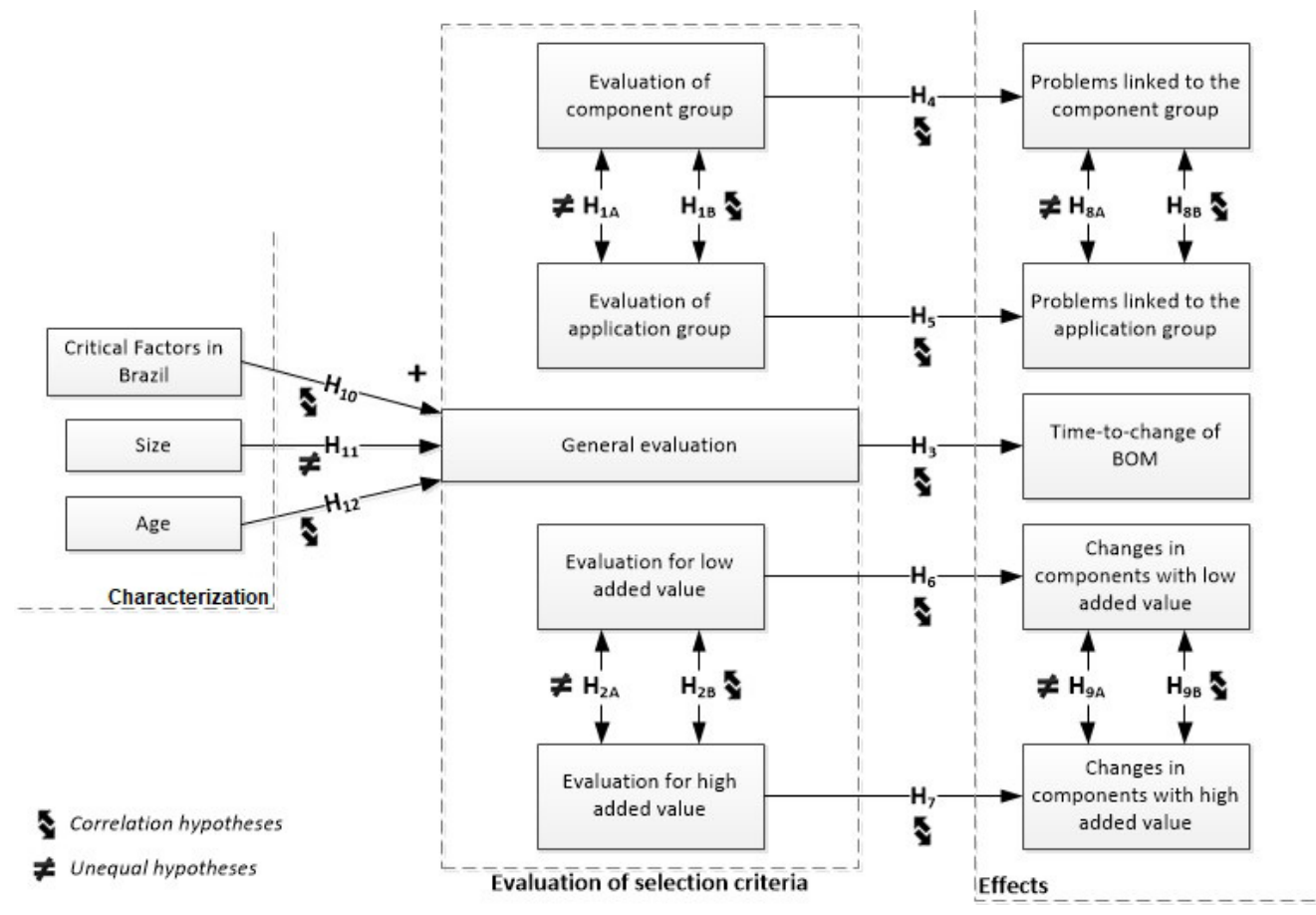

Figure 1. Theoretical model of the study. 
statistical power $1-\beta=0.9$; and effect size between medium and low $(0.2<\mathrm{f}<0.5)$. These values were calculated to have high statistical quality for the theme of this research conducted by Verma and Goodale (1995) and Forza (2002). Considering that the final population is finite, the finite population correction factor (fpc) was utilized, as suggested by Hair Junior et al. (2003) and Kirk (2008), resulting in a sample size of $\mathrm{n}=75$ elements for the representativeness desired.

\subsection{Measures}

The questionnaire was developed and validated using two tests. The objective of the first validation was to evaluate understanding of terms, instructions, and proposed scales. Two specialists in electronic component selection in companies with the characteristics used for the study population were invited to fill out the questionnaire. In this step, it was shown that the specialists easily understood the questions. They suggested only changes in the order of some of them.

The second validation was applied to analyze the internal reliability of the measures brought up by the questionnaire. For this purpose, the survey was given to 10 respondents chosen for convenience as a pilot test. Internal reliability was evaluated by means of the Cronbach $\alpha$ calculation, a practice that is common in operations management (RUNGTUSANATHAN et al., 2003). This study only evaluated the internal reliability of constructs whose measures are made up of the sum of points from three or more questions. Table 2 shows the constructs referring to the importance of selection criteria for components with the questions used to measure them and the Cronbach $\alpha$ calculated from the data of the pilot test.

Table 2 shows that different constructs share the same survey question. This strategy was utilized in order to optimize the number of questions capable of measuring these constructs, a practice suggested by Melnyk et al. (2012). Table 3 shows the constructs referring to the reasons and changes of the BOM of products with the research questions used to measure them and the Cronbach $\alpha$ calculated (when applicable) using the pilot test data.

In, Table 4, the organization is described with the survey questions that measure it and the Cronbach $\alpha$ calculated (when applicable) utilizing the pilot test data. To identify the constructs related to size and area, the same criteria were selected as in ABINEE (ASSOCIAÇÃO..., 2010). An open question was used regarding age. Finally, to identify the problems generated by the situation companies face in Brazil, there were 6 questions based on the critical factors reported in the literature.

The scale used to identify each difficulty that constitutes the critical factors was a Likert scale with only two items. A zero indicates that the company does not have the problem specified, and a 1 identifies that the company has the problem. The construct "critical factors in Brazil" is a result of the sum of the measurements obtained for each problem, varying between 0 and 6 depending on the influence this factor has in the organization.

Note that in Tables 2, 3, and 4, all of the constructs are composed of summed scales that require an internal

Table 2. Measuring questions and Cronbach's Alpha of the constructs that evaluated the selection criteria.

\begin{tabular}{|c|c|c|}
\hline Construct & Research question* & $\alpha$ \\
\hline \multirow{8}{*}{ HVE. Evaluation of components with high added value** } & Q1. Manufacturer & \multirow{8}{*}{0.8502} \\
\hline & Q2. Supplier & \\
\hline & Q3. Family of the component & \\
\hline & Q4. Information access & \\
\hline & Q5. Performance & \\
\hline & Q6. Reliability & \\
\hline & Q7. Assembly & \\
\hline & Q8. Obsolescence & \\
\hline \multirow{8}{*}{ LVE. Evaluation of components with low added value $* * *$} & Q9. Manufacturer & \multirow{8}{*}{0.6816} \\
\hline & Q10. Supplier & \\
\hline & Q11. Family of the component & \\
\hline & Q12. Information access & \\
\hline & Q13. Performance & \\
\hline & Q14. Reliability & \\
\hline & Q15. Assembly & \\
\hline & Q16. Obsolescence & \\
\hline CGE. Evaluation of component group & Questions Q1 to Q4 and Q9 to Q12. & 0.8793 \\
\hline AGE. Evaluation of application group & Questions Q5 to Q8 and Q13 to Q16. & 0.8350 \\
\hline GE. General evaluation & Questions Q1 to Q16. & 0.8209 \\
\hline
\end{tabular}

*Options: 1 (not very important) to 5 (very important); ** Evaluate the level of importance for components with high added value for each of these criteria; *** Evaluate the level of importance for components with low added value for each of these criteria. 
Table 3. Measurement questions and Cronbach's Alpha of the constructs of the effects of selection criteria.

\begin{tabular}{|c|c|c|}
\hline Construct & Study question & $\alpha$ \\
\hline \multirow{4}{*}{ TTC. Time-to-change of BOM } & Time between product launch and the need to the change of BOM:* & \multirow{4}{*}{0.6486} \\
\hline & Q17. No PCB rework & \\
\hline & Q18. PCB rework required & \\
\hline & Q19. Total PCB rework required & \\
\hline \multirow{5}{*}{ CGP. Problems linked to the component group } & Frequency of BOM changes due to:** & \multirow{5}{*}{0.8982} \\
\hline & Q20. Component became obsolete without notification & \\
\hline & Q21. Manufacturer modified the component & \\
\hline & Q22. Didn't behave as specified & \\
\hline & Q23. Unreliable as specified & \\
\hline AGP. Problems linked to the application group & $\begin{array}{l}\text { Frequency of BOM changes due to:** } \\
\text { Q24. Component became obsolete, but it was anticipated } \\
\text { Q25. Incompatible with assembly } \\
\text { Q26. Design error }\end{array}$ & 0.7553 \\
\hline LVC. Changes in components with low added value & $\begin{array}{l}\text { Q27. Frequency of BOM changes for components with low added } \\
\text { value** }\end{array}$ & Not applicable \\
\hline $\begin{array}{l}\text { HVC. Changes in components with high added } \\
\text { value }\end{array}$ & $\begin{array}{l}\text { Q28. Frequency of BOM changes for components with high added } \\
\text { value** }\end{array}$ & Not applicable \\
\hline
\end{tabular}

*Options: 1: less than 1 year; 2: from 1 to 3 years; 3 : from 3 to 6 years; 4: from 6 to 10 years; 5 : more than 10 years; **Options: $1: 1$ (uncommon) to 5 (very common).

Table 4. Measurement questions and Cronbach's Alpha of the constructs used to describe organizations.

\begin{tabular}{|c|l|c|}
\hline Construct & \multicolumn{1}{|c|}{ Survey question } & \multicolumn{1}{|c|}{$\alpha$} \\
\hline CS. Company's size & Q29. How many employees does the company have?* & Not applicable applicable \\
\hline CA. Company's age & Q30. How long has the company existed for?** & \\
& Identify the problems found in your company during component selection:*** & \\
& Q32. Obtaining samples for tests & 0.8106 \\
& Q33. Unsatisfactory technical support & \\
BCF. Critical factors in Brazil & Q34. Concern about counterfeit components & \\
& Q35. Access to technical guidelines & \\
& Q36. Dissatisfaction with suppliers & \\
& Q37. Bureaucracy in incentives policies & \\
\hline
\end{tabular}

*Options: 1: from 1 to 9 employees; 2: from 10 to 99 employees; 3: from 100 to 499 employees; 4: more than 500 employees; ** Options: Open question; ***Options: 0: Problem not found; 1: Problem found.

reliability test obtained a Cronbach $\alpha$ of 0.6 , validating the survey within the criteria utilized for this study.

\subsection{Data collection}

Data was collected using an online survey software. Many authors have discussed this practice as a tool for applying surveys. They conclude that the procedure can be effective when used along with other activities such as: preliminary phone contact; identification of the correct respondent; and telephone follow-up for those that do not respond or have incomplete responses (KLASSEN; JACOBS, 2001; TSIKRIKTSIS, 2005; SAUNDERS, 2012).

Following these premises, the first part of the data collection procedure was initial contact by phone in order to identify the best person to take part in the survey. Then, the questionnaire was given using web software. Up to three weekly follow-ups were carried out by phone to deal with those who did not respond. Incomplete or invalid responses were managed in the same way. Only complete responses were included in the data analysis, which is a common practice in operations management, according to Tsikriktsis (2005).

The initial moment adopted for the procedure was when the questionnaire was sent to the first candidate for response and the last moment ended when the last respondent was declared valid, non-responding, or discarded. This means that data collection did not finish when a specified number of valid responses were reached, but when all of the activities of the procedure had been applied to all of the sample elements.

In total, the procedure lasted 75 days; the return rate was $65.33 \%$ (49 respondents). This value was considered acceptable by Malhotra and Grover (1998) and Forza (2002), in addition of being above average when compared to the response rates of other surveys in periodicals such as Journal of Operations Management, Production and Operations Management, and Decision Sciences (MELNYK et al., 2012). The respondents were constituted of: 8 micro-companies (16\%); 24 small companies (49\%); 
14 average-sized companies (29\%); and 3 large companies (6\%). There were 9 companies with less than 10 years in operation (18\%); 14 between 11 and 20 years in operation (29\%); 18 between 21 and 30 years in operation (37\%); and 8 with more than 31 years in operation $(16 \%)$. When compared to other studies utilizing similar populations in Brazil, such as in ABINEE (ASSOCIAÇÃO..., 2010); Jabbour et al. (2011); Scandelari and Cunha (2013), it should be noted that the respondents of this study had greater percentages of small companies and new companies. This could have been a result of the eliminations carried out to define the population, since according to BNDES (BANCO..., 2010), large companies are mainly foreign and import component kits that have already been selected abroad, which prohibits them from participating in this study.

A descriptive summary of the data collected is shown in Tables 5 and 6 . Table 5 shows the average, median, and standard deviation of the importance of each criterion in component selection for components with high and low added value.

Similarly, Table 6 shows the results for the variables and constructs referring to measure changes in the BOM.

\section{Results}

The one-way ANOVA F-test was used to test the hypotheses determine if there was a difference between average values of the constructs. In this study, the ANOVA tests used the proposal that the averages are not equal to a null hypothesis (H0). Therefore, when the p-value was less than $0.05, \mathrm{H} 0$ was rejected, which showed that there were significant differences among the constructs and the groups evaluated. Table 7 shows the results of hypothesis tested using ANOVA.

The Pearson correlation method was used for the hypotheses that tested the correlation between the constructs. The method measures the linear association between two metric variables. A P-value lower than 0.05 shows that the correlation is statistically significant. The correlation coefficient allows the strength and direction of the correlation to be evaluated. In these cases, the null hypothesis $(\mathrm{H} 0)$ shows that there is no correlation between the constructs; therefore, $\mathrm{H} 0$ is rejected when the p-value is lower than 0.05 , showing that the correlation is statistically significant. Table 8 shows the results of hypothesis testing using Pearson correlation.

Table 5. Importance of selection criteria for components with high and low added value.

\begin{tabular}{|c|l|c|c|c|c|c|c|}
\hline \multirow{2}{*}{ Group } & \multicolumn{2}{|c|}{ Selection Criteria } & \multicolumn{3}{|c|}{ High Added Value } & \multicolumn{3}{c|}{ Low Added Value } \\
\cline { 2 - 7 } & & AVG & MDN & SD & AVG & MDN & SD \\
\hline \multirow{4}{*}{ Component } & Manufacturer & 4.3878 & 5.0000 & 0.9313 & 3.7551 & 4.0000 & 1.2505 \\
\cline { 2 - 7 } & Supplier & 3.9184 & 4.0000 & 1.0961 & 3.4898 & 4.0000 & 1.1924 \\
\cline { 2 - 7 } & Component Family & 4.1020 & 4.0000 & 0.9184 & 3.5102 & 3.0000 & 1.1924 \\
\cline { 2 - 7 } & Access to information & 4.5714 & 5.0000 & 0.5774 & 4.0408 & 4.0000 & 1.0985 \\
\hline \multirow{4}{*}{ Application } & Performance & 4.7755 & 5.0000 & 0.5868 & 4.6327 & 5.0000 & 0.6675 \\
\cline { 2 - 8 } & Reliability & 4.7755 & 5.0000 & 0.5502 & 4.5306 & 5.0000 & 0.8191 \\
\cline { 2 - 8 } & Assembly Compatibility & 4.2245 & 4.0000 & 0.7975 & 4.1224 & 4.0000 & 0.8571 \\
\cline { 2 - 8 } & Obsolescence & 4.4898 & 5.0000 & 0.7671 & 4.1020 & 4.0000 & 0.9409 \\
\hline
\end{tabular}

AVG: Average; MDN: Median; SD: Standard Deviation.

Table 6. Changes in the BOM linked to evaluation of selection criteria.

\begin{tabular}{|l|r|r|r|}
\hline \multicolumn{1}{|c|}{ Construct and variables } & AVG & MDN \\
\hline \multicolumn{2}{|c|}{ SD } \\
\hline Time until changes in the BOM & 1.7143 & 1.0000 & 0.9574 \\
\hline Need for changes in the BOM without reworking the PCB & 2.2449 & 2.0000 & 0.9249 \\
\hline Need for changes in the BOM with partial rework of the PCB & 3.4082 & 3.0000 & 1.0785 \\
\hline Need for changes in the BOM with total rework of the PCB & 1.7143 & 1.0000 & 0.9574 \\
\hline Need for changes in the BOM without reworking the PCB & 2.6939 & 3.0000 & 1.2282 \\
\hline Frequency of changes in the BOM for reasons linked to the component group & 1.4898 & 1.0000 & 0.8926 \\
\hline Component obsolete without previous notification & 1.7346 & 2.0000 & 0.8107 \\
\hline Manufacturer altered the component without previous notification & 1.6939 & 1.0000 & 1.0248 \\
\hline Did not perform its function as specified & \multicolumn{2}{|c|}{} \\
\hline Not reliable as specified & 2.8776 & 3.0000 & 1.2355 \\
\hline Frequency of changes in the BOM for reasons linked to the application group & 1.9591 & 2.0000 & 1.0198 \\
\hline Component obsolete with previous notification & 2.3673 & 2.0000 & 1.0742 \\
\hline Incompatibility with the company's assembly process & 3.1020 & 3.0000 & 1.3730 \\
\hline Design error & 2.1837 & 2.0000 & 1.1119 \\
\hline Frequency of changes in the BOM for reasons linked to the component group & & \\
\hline Frequency of changes in the BOM for components with high added value & & \\
\hline
\end{tabular}

BOM: Bill of Materials; PCB: Printed Circuit Board; AVG: Average; MDN: Median; SD: Standard Deviation. 
Table 7. Results of hypothesis testing using ANOVA.

\begin{tabular}{|c|c|c|c|c|}
\hline Hypothesis & Construct Compared & One-way ANOVA F* & P-value** & Result \\
\hline $\mathrm{H}_{1 \mathrm{~A}}$ & LVE x HVE & 11.82 & 0.001 & Accept \\
\hline $\mathrm{H}_{2 \mathrm{~A}}$ & CGE x AGE & 16.39 & 0.000 & Accept \\
\hline $\mathrm{H}_{8 \mathrm{~A}}$ & CGP x AGP & 16.52 & 0.000 & Accept \\
\hline $\mathrm{H}_{9 \mathrm{~A}}$ & LVC x HVC & 13.24 & 0.000 & Accept \\
\hline $\mathrm{H}_{11}$ & GE x CS & 1.59 & 0.206 & Reject \\
\hline
\end{tabular}

*(0.01; 2.96); **Two-tailed significance level = 0.01. LVE: Evaluation of components with low added value; HVE: Evaluation of components with high added value; CGE: Evaluation of component group; AGE: Evaluation of application group; CGP: Problems linked to the component group; AGP: Problems linked to the application group; LVC; Changes in components with low added value.

Table 8. Results of hypothesis testing using pearson correlation.

\begin{tabular}{|c|c|c|c|c|}
\hline Hypothesis & Construct Compared & $\begin{array}{c}\text { Pearson correlation } \\
\text { coefficient }\end{array}$ & P-value* & Result \\
\hline $\mathrm{H}_{1 \mathrm{~B}}$ & LVE x HVE & 0.530 (moderate) & 0.000 & Accept \\
\hline $\mathrm{H}_{2 \mathrm{~B}}$ & CGE x AGE & 0.342 (small) & 0.016 & Recept \\
\hline $\mathrm{H}_{3}$ & GE x TTC & -0.036 & 0.805 & Reject \\
\hline $\mathrm{H}_{4}$ & CGE x CGP & 0.021 & 0.885 & Reject \\
\hline $\mathrm{H}_{5}$ & AGE x AGP & -0.167 & 0.252 & Reject \\
\hline $\mathrm{H}_{6}$ & LVE x LVC & -0.106 & 0.468 & Reject \\
\hline $\mathrm{H}_{7}$ & HVE x HVC & 0.191 & 0.189 & Accept \\
\hline $\mathrm{H}_{8 \mathrm{~B}}$ & CGP x AGP & 0.476 (moderate) & 0.001 & Reject \\
\hline $\mathrm{H}_{9 \mathrm{~B}}$ & LVC x HVC & -0.053 & 0.034 & Accept \\
\hline $\mathrm{H}_{10}$ & GE x BCF & 0.303 (small) & 0.148 & Reject \\
\hline $\mathrm{H}_{12}$ & GE x CA & 0.210 & & \\
\hline
\end{tabular}

*Two-tailed significance level $=0.01$. LVE: Evaluation of components with low added value; HVE: Evaluation of components with high added value; CGE: Evaluation of component group; AGE: Evaluation of application group; GE: General evaluation; TTC: Time-to-change of BOM; CGE: Evaluation of component group; CGP: Problems linked to the component group; AGE: Evaluation of application group; AGP: Problems linked to the application group; LVC; Changes in components with low added value; HVC: Changes in components with high added value; BCF: Critical factors in Brazil; GE: General evaluation; CA; Company's age.

\section{Discussion}

\subsection{Evaluation of selection criteria}

Regarding the importance of the selection criteria, there are two crucial points to be analyzed in the results. First of all, the fact that $\mathrm{H}_{2 \mathrm{~A}}$ was accepted shows that there was differentiation in the evaluation of components between the criteria of the application group and criteria of the component group. The importance of selection criteria that consider the environment of the product is different from the importance of criteria that do not consider it. For Jackson et al. (1999), the level of importance the company assigns to each group of criteria varies from case to case. The results show that in the sample studied, the criterion of the application group is more important than the component group.

The fact that $\mathrm{H}_{2 \mathrm{~B}}$ was accepted shows that for companies in which application group selection criteria are essential, component group selection criteria is also very considerable. This suggests that the companies in the sample tend to be different in terms of importance level of the criteria in a general form and not a specific group of criteria.
The second point in this analysis is the difference in importance of the selection criteria between components with high and low added value, which is shown because $\mathrm{H}_{1 \mathrm{~A}}$ was not rejected. This difference is also handled in some PDP models for the electronics industry found in the literature. In this study, the results show that they are different though. The sample companies consider the selection criteria of components with high added value of being more relevant than those with low added value.

In addition, the fact that $\mathrm{H}_{1 \mathrm{~B}}$ was not rejected suggests that for companies in which high-added-value component selection criteria are very important, low-added-value component selection is also very considerable. Thus, what makes them different is again the level of importance of the criteria in a general form, and not whether the component has high or low added value.

\subsection{Consequences linked to selection criteria}

The first result to be analyzed is related to the time between product launch and the need to change the BOM. In the cases in which the PCB did not have to be altered, the change in BOM occurred in up to 1 year after product launch for more than half of the companies surveyed. If the PCB 
had to be partially altered, a change in BOM was needed in up to 3 years for more than $70 \%$ of the respondents.

The second result to be discussed is related to changes in the BOM caused by problems linked to criteria evaluation of the application group and component group. In accepting $\mathrm{H}_{8 \mathrm{~A}}$, there is evidence that the BOM is altered more frequently because of problems linked to the application group than to the component group. This means that the companies in the sample indicate that it is more common to alter the BOM in products due to poor evaluations between the specifications of components and the product environment, (LCEP) rather of problems resulting purely from the manufacturers or distributors of components, which is also observed in the high frequency indicated for design errors. In other words, more BOM components were changed because of internal errors than external problems.

Accepting hypothesis H8B shows that as the occurrence of problems linked to one group of criteria becomes more common, the same takes place in the other group. This suggests that the companies in the sample tend to be different in how they indicate the frequency of changes to the BOM independently of the group of criteria that the alteration is related to.

It is important to identify component obsolescence as a major factor in causing changes to the BOM, both for cases in which the company was notified that the component would become obsolete and in cases where the organization was surprised by a component's obsolescence without any notification from the manufacturer or distributor. This result corroborated Bradley and Guerrero (2008), Rojo et al. (2010), and Sandborn et al. (2011) who pointed to component obsolescence as the most serious problem in developing electronic products. Guideline ANSI EIA 4899 also recommends that component availability and the risk of obsolescence be considered the most important selection criteria (GOVERNMENT..., 2002).

The fact that H9A was accepted shows that the companies in the sample need to alter components with low added value more often than those with high added value. A possible explanation for this phenomenon is that the change of components with low added value requires fewer changes in the product (BANC; GUINET; DOCHE, 2012). This allows the company's purchasing department to work with different components to make the product's price more competitive (HASKELL, 2004).

At the same time, rejecting $\mathrm{H}_{9 \mathrm{~B}}$ shows that companies are not different only in terms of how often there must be changes in components. The changes of components with low and high added value differs from one company to the next. This result was unique among those obtained with tests for similar hypotheses, such as $\mathrm{H}_{2 \mathrm{~B}}, \mathrm{H}_{1 \mathrm{~B}}$, and $\mathrm{H}_{8 \mathrm{~B}}$, in which the hypotheses were accepted.

A company that indicates that it commonly changes high-added-value components also tends to indicate the same for low-added-value components, and vice versa. This phenomenon could be associated with the large variety of types of electronic products. The difference between levels of components with high or low value depends on the type of product, and the way companies adopt selection criteria varies from case to case (BANC; GUINET; DOCHE, 2012; CHALLA; RUNDLE; PECHT, 2013).

\subsection{Relationships between description, evaluation, and effect constructs}

The relationships that involve the description of an organization and the importance given to selection criteria were analyzed by testing $\mathrm{H}_{10}$ to $\mathrm{H}_{12}$. Although Banc et al. (2012) and Challa et al. (2013) point out that companies with different characteristics can evaluate components differently, only hypothesis $\mathrm{H} 10$ was accepted. In this study, the results show that the statistical importance of the selection criteria is the same for the companies in the sample, independent of size or age.

However, the fact that $\mathrm{H}_{10}$ was accepted shows that the influence of critical factors in an organization in Brazil positively correlates with the importance of selection criteria. Thus, difficulties, such as obtaining samples for testing, concern with counterfeit components and lack of technical support influence the selection of components.

Relationships that involve selection criteria constructs and the consequences linked to them were analyzed by hypothesis $\mathrm{H}_{3}$ to $\mathrm{H}_{7}$; they were rejected by the tests. This shows that evaluating a group of criteria or components as being more important does not mean that the consequences linked to the group are more or less common.

Many authors have suggested that the evaluation of the selection criteria can influence the frequency in changes to the BOM (PECHT, 2004; YANG et al., 2011; MURRAY et al., 2002; GOEL; GRAVES, 2006). However, even when this influence has not been found in the research results, it should be emphasized that these results do not support or reject the suggestions of those authors. The objective of the use of the method is not to test the causal relationships between the constructs, but to identify trends in the distribution of the importance of selection criteria and the distribution of frequency in changes to the BOM.

\section{Conclusions, limitations and recommendations}

Components with higher added value are considered to be more considerable during selection than components with lower added value. However, BOM changes after a product has been launched on the market are more common for components with low added value than for components with high added value. This means that companies prefer to emphasize the importance of components with high added value even though they are aware that changes in the product are more common with components with low added value. 
It is not the number of changes of a type of component that influences its importance during selection, but the risk of rework involved if the component has to be altered.

This affirmation corroborates the results indicated by the companies for the time between product launch and the need to alter the BOM. For the study population, changes to the $\mathrm{BOM}$ are common. The key question to be evaluated at this moment is the risk involved in the alteration. Components with lower added value can be substituted for others that have the same function without changing the PCB, while components with higher added value generally involve drastic changes and are consequently riskier. In this context, there are practices that can limit this risk, such as applying the Design for Minimum Risk concept. An example would be preparing the PCB of the product to be assembled not only with the original component listed on the BOM, but also with other possible substitutes that have the same function.

Companies use selection criteria differently. There is a distinction between the importance of the criteria that consider the product environment and those that do not consider it. The results show that the criteria involving the evaluation of a component without considering the product environment are seen as less relevant than those that consider it. Even so, the reasons that are most likely to cause BOM changes are those that involve poor evaluations of compatibility between the component and the product environment. Therefore, it can be mentioned that companies pay more attention to the criteria related to the most common problems, sharing responsibility for component evaluation with manufacturers and suppliers.

It is important to emphasize the incompatibility between the life cycle of the component and the product as a serious problem in the research population. It is possible that the risk of obsolescence is being ignored or that companies simply do not believe that there is a solution for the problem. It should be considered that the participation of companies in the research population in the market allotment of the component manufacturers is probably significantly smaller than the one of large multinationals in the electronics industry. This could discourage Brazilian companies from seeking solutions for the obsolescence of the components that they utilize, because their market share is not attractive enough.

The results of this study show the gravity of the problem. It is important for Brazilian companies to: be conscious of the risk of obsolescence when choosing a component; be prepared with a reaction for the possible obsolescence of a component; and determine whether notifications of the obsolescence of a component that come from the manufacturer or supplier are accessible and carried out quickly.
Also note the delicate role that the suppliers have for the population of the survey. Some of the critical factors indicated by the companies that have more influence on component selection are strongly linked to suppliers, such as difficulty in obtaining samples, unsatisfactory customer support, and concern about acquiring counterfeit parts. The population of the survey indicated that the evaluation of the component supplier was not an important criterion when selecting a component. It could be said that companies select the component and not the supplier. In some cases, this can lead them to acquire components from bad suppliers.

The only characteristic of the organization correlated with the evaluation of selection criteria is the level of influence that the critical factors in Brazil have on companies. Therefore, Brazilian characteristics, such as the lack of component manufacturers and the bureaucratic hurdles to participating in incentive programs, are influential for the way companies select components.

The results and conclusions of this study are limited to the list of 255 companies that make up the population represented by the sample. Carrying out this survey on a larger scale or one from other countries would provide important comparative results, if the characteristics imposed by this study for the elements of the population were maintained.

This study has transversal characteristics, so there is no way to evaluate causal relationships among the different constructs. An interesting contribution to the theme would be to use an action study to analyze the causal relationship between evaluations of selection criteria and the frequency and reasons for BOM changes in products. This would allow the criteria or practices which are more or less relevant in reducing the number of product changes to be identified.

\section{Acknowledgements}

The authors need to express their acknowledgments to two Brazilian research agencies: the CAPES Foundation (Grant No. PE024/2008) and FAPEMIG (Grant No. PPM-00586), and especially all respondents.

\section{References}

ASHMORE, C. Heterogeneous assembly. Circuits Assembly, v. 18, n. 9, p. $28,2007$.

ASSOCIAÇÃO BRASILEIRA DA INDÚSTRIA ELÉTRICA E ELETRÔNICA - ABINEE. Consolidação da Pesquisa com as Pequenas e Médias Empresas do Setor Eletroeletrônico. 2010. Available from: <http://www. abinee.org.br>. Access in: 15 Aug 2018.

ASSOCIAÇÃO BRASILEIRA DA INDÚSTRIA ELÉTRICA E ELETRÔNICA - ABINEE. Panorama Econômico e Desempenho Setorial. 2013. Available from: $<$ http://www. abinee.org.br>. Access in: 28 Aug 2018. 
BANC, C.; GUINET, J.; DOCHE, E. High performance electronics in long lifetime, continuous operation, industrial products: The art of balancing conflicting interests. Microelectronics and Reliability, v. 52, p. 1797-1802, 2012.

BANCO NACIONAL DO DESENVOLVIMENTO BNDES. Complexo Eletrônico: Lei de Informática e competitividade. 2010. Available from: <http://www.bndes. gov.br>. Access in: 31 Aug 2018.

BRADLEY, R. J.; GUERRERO, H. H. Product design for life-cycle mismatch. Production and Operations Management, v. 17, n. 5, p. 497-512, 2008.

CHALLA, V.; RUNDLE, P.; PECHT, M. G. Challenges in the qualification of electronic components and systems. IEEE Transactions on Device and Materials Reliability, v. 13, n. 1, p. 26-35, 2013.

CHATTERJEE, K.; DAS, D. Semiconductor manufacturers' efforts to improve trust in the electronic part supply chain. IEEE Transactions on Components and Packaging Technologies, v. 30, n. 3, p. 547-549, 2007.

CONFEDERAÇÃO NACIONAL DA INDÚSTRIA - CNI. Sindicatos - Por estado. 2017. Available from: $<$ http:// www.portaldaindustria.com.br>. Access in: 7 July 2018.

CORCORAN, P. Change and the consumer electronics industry. IEEE Consumer Electronics Magazine, v. 1, n. 4, p. 3-16, 2012.

DAS, D. et al. Deciphering the deluge of data. Circuits and Devices Magazine, v. 16, n. 5, p. 26-34, 2000.

DEFENSE STANDARDIZATION PROGRAM OFFICE DSPO. SD-19: parts management guide. 2013. Available from: <www.dscc.dla.mil>. Access in: 23 Aug 2018.

DEPARTMENT OF DEFENSE - DOD. MIL-STD-3018 Parts Management (w/ change-2). 2015. Available from: $<$ www.dscc.dla.mil>. Access in: 1 Aug 2018.

EPPINGER, S. D.; CHITKARA, A. R. The practice of global product development. MIT Sloan Management Review, v. 50437, p. 1-11, 2009.

FORZA, C. Survey research in operations management: a process-based perspective. International Journal of Operations \& Production Management, v. 22, n. 2, p. 152-194, 2002.

FOUCHER, B. et al. Why a new parts selection and management program? IEEE Transactions on Components, Packaging, and Manufacturing Technology - Part A, v. 21, n. 2, p. 375-382, 1998.

GAUSEMEIER, J.; DUMITRESCU, S. K.; NORDSIEK, D. Integrative development of product and production system for mechatronic products. Robotics and Computerintegrated Manufacturing, v. 27, n. 4, p. 772-778, 2011.
GOEL, A.; GRAVES, R. J. Electronic system reliability: collating prediction models. IEEE Transactions on Device and Materials Reliability, v. 6, n. 2, p. 258-265, 2006.

GOVERNMENT ELECTRONICS AND INFORMATION TECHNOLOGY ASSOCIATION - GEIA. EIA4899: standard for preparing an electronic components management plan. 2002.

GRIFFIN, A. et al. Voices from the field: how exceptional electronic industrial innovators innovate. Product Innovation Management, v. 26, p. 222-240, 2009.

GUTIERREZ, A.; OROZCO, J.; SERRANO, A. Factors affecting IT and business alignment: a comparative study in SMEs and large organisations. Journal of Enterprise Information Management, v. 22, n. 1-2, p. 197-211, 2009.

HAIR JUNIOR, J. F. et al. Essentials of business research methods. Armonk: ME Sharpe, 2003.

HASKELL, B. Portable electronics product design and development. New York: McGraw Hill, 2004.

HAUSER, G. et al. Indústria eletrônica no Brasil e na China: um estudo comparativo e a análise das políticas públicas de estímulo a capacidade tecnológica do setor. Journal of Technology Management \& Innovation, v. 2, n. 3, p. 85-96, 2007.

HELO, P. Managing agility and productivity in the electronics industry. Industrial Management \& Data Systems, v. 104, n. 7, p. 567-577, 2004.

HUNT, I.; JONES, R. Winning new product business in the contract electronics industry. International Journal of Operations \& Production Management, v. 18, n. 2, p. 130-142, 1998.

INTERNATIONAL ELECTROTECHNICAL COMISSION - IEC. IEC quality assessment system for electronic components: principles for the implementation of an ECMP plan. 2008. Available from: <http://www.iecq-cert.org/>. Access in: 21 Aug 2018.

IYER, A.; SARANGA, H.; SESHADRI, S. Effect of quality management systems and total quality management on productivity before and after: empirical evidence from the indian auto component industry. Production and Operations Management, v. 22, n. 2, p. 283-301, 2013.

JABBOUR, A. B. et al. Relationships between company size, production system and supply chain: evidence from electro-electronics sector in Brazil. Journal of Advances in Management Research, v. 8, n. 1, p. 30-52, 2011.

JACKSON, M. et al. A risk-informed methodology for parts selection and management. Quality and Reliability Engineering International, v. 15, n. 4, p. 261-271, 1999.

KHAN, Z. Design for assembly. Assembly Automation, v. 28, n. 3, p. 200-206, 2008. 
KIM, K. Future silicon technology. In: EUROPEAN SOLIDSTATE DEVICE RESEARCH CONFERENCE, 2012, Bordeaux. Proceedings... Piscataway, NJ: IEEE, 2012. p. 1-6.

KIRK, R. E. Statistics: an introduction. 5th ed. Belmont: Thompsom, 2008.

KLASSEN, D.; JACOBS, J. Experimental comparison of web, electronic and mail survey technologies in operations management. Journal of Operations Management, v. 19, p. 713-728, 2001.

KRISHNAN, V.; ULRICH, K. T. Product development decisions: a review of the literature. Management Science, v. 47, n. 1, p. 1-21, 2001.

LAU, R. S. M. Competitive factors and their relative importance in the US electronics and computer industries. International Journal of Operations \& Production Management, v. 22, n. 1, p. 125-135, 2002.

LEAHY, K.; OSTER, G. The evolution of electronic systems technology and its impact on methods of innovation. Regent Global Business Review, v. 5, n. 2, p. 8-15, 2012.

LEDWITH, A. Management of new product development in small electronics firms. Journal of European Industrial Training, v. 24, n. 2-4, p. 137-148, 2000.

LI, Y.; LIU, Y.; LIU, H. Co-opetition, distributor's entrepreneurial orientation and manufacturer's knowledge acquisition: evidence from China. Journal of Operations Management, v. 29, n. 1, p. 128-142, 2011.

LIVINGSTON, H. Avoiding counterfeit electronic components. IEEE Transactions on Components and Packaging Technologies, v. 30, n. 1, p. 187-189, 2007.

MALHOTRA, M. K.; GROVER, V. An assessment of survey research in POM: from constructs to theory. Journal of Operations Management, v. 16, n. 4, p. 407-425, 1998.

MALLICK, D. N.; SCHROEDER, R. G. An integrated framework for measuring product development performance in high technology industries. Production and Operations Management, v. 24, n. 2, p. 142-158, 2005.

MCIVOR, R.; HUMPHREYS, P.; CADDEN, T. Supplier involvement in product development in the electronics industry: a case study. Journal of Engineering and Technology Management, v. 23, n. 4, p. 374-397, 2006.

MELNYK, S. A. et al. Would you mind completing this survey: assessing the state of survey research in supply chain management. Journal of Purchasing and Supply Management, v. 18, n. 1, p. 35-45, 2012.

MILLSON, R. M.; WILEMON, D. Driving new product success in the electrical equipment manufacturing industry. Technovation, v. 26, p. 1268-1286, 2006.

MINDERHOUD, S.; FRASER, P. Shifting paradigms of product development in fast and dynamic markets.
Reliability Engineering \& System Safety, v. 88, n. 2, p. 127-135, 2005.

MOUlianitis, V. C.; ASPRAGAThOS, N. A.; DENTSORAS, A. J. A model for concept evaluation in design - an application to mechatronics design of robot grippers. Mechatronics, v. 14, n. 6, p. 599-622, 2004.

MURRAY, S.; BORU, M.; PECHT; M. G.; ERHART, D. Tracking semiconductor part changes through the part supply chain. IEEE Transactions on Components and Packaging Technologies, v. 25, n. 2, p. 230-238, 2002.

NORDIN, N.; DEROS, B. M.; WAHAB, D. A. Lean manufacturing implementation in malaysian automotive industry: an exploratory study. Operations and Supply Chain Management, v. 4, n. 1, p. 21-30, 2011.

PECHT, M. G. Parts selection and management. Hoboken: John Wiley \& Sons, 2004.

PECHT, M. G.; TIKU, S. Bogus: electronic manufacturing and consumers confront a rising tide of counterfeit electronics. Spectrum, v. 43, n. 5, p. 37-46, 2006.

REDDI, K. R.; MOON, Y. B. Simulation of new product development and engineering changes. Industrial Management \& Data Systems, v. 112, n. 4, p. 520-540, 2011.

ROJO, J. R.; ROY, R.; SHEHAB, E. Obsolescence management for long-life contracts: state of the art and future trends. International Journal of Advanced Manufacturing Technology, v. 49, n. 9-12, p. 1235-1250, 2010.

RUNGTUSANATHAN, M. J. et al. Survey research in operations management: historical analyses. Journal of Operations Management, v. 21, n. 4, p. 475-488, 2003.

SANDBORN, P.; PRABHAKAR, V.; AHMAD, O. Forecasting electronic part procurement lifetimes to enable the management of DMSMS obsolescence. Microelectronics and Reliability, v. 51, n. 2, p. 392-399, 2011.

SAUNDERS, M. N. K. Web versus mail: the influence of survey distribution mode on employees' response. Field Methods, v. 24, n. 1, p. 56-73, 2012.

SCANDELARI, V. D. R. N.; CUNHA, J. C. D. Ambidextrality and the socioenvironmental performance of companies in the electro-electronic sector. Revista de Administração de Empresas, v. 53, n. 2, p. 183-198, 2013.

SHIPP, S. S. et al. Advancing manufacturing to new frontiers: increasing opportunities for society. Innovations: Technology, Governance, Globalization, v. 7, n. 3, p. 71$81,2012$.

SHUNK, D. L. et al. Electronics industry drivers of intermediation and disintermediation. International Journal of Physical Distribution \& Logistics Management, v. 37, n. 3, p. 248-261, 2007. 
SOOD, B.; DAS, D.; PECHT, M. G. Screening for counterfeit electronic parts. Journal of Materials Science Materials in Electronics, v. 22, n. 10, p. 1511-1522, 2011.

SYRUS, M.; PECHT, M. G.; HUMPHREY, D. Part assessment guidelines and criteria for parts selection and management. IEEE Transactions on Electronics Packaging Manufacturing, v. 24, n. 4, p. 339-350, 2001.

TRIPATHY, A.; EPPINGER, S. D. Organizing global product development for complex engineered systems. IEEE Transactions on Engineering Management, v. 58, n. 3, p. 510-529, 2011.

TSIKRIKTSIS, N. A review of techniques for treating missing data in OM survey research. Journal of Operations Management, v. 24, n. 1, p. 53-62, 2005.
VERMA, R.; GOODALE, J. C. Statistical power in operations management research. Journal of Operations Management, v. 13, n. 2, p. 139-152, 1995.

YANG, L. et al. Design-for-reliability implementation in microelectronics packaging development. Microelectronics International, v. 28, n. 1, p. 29-40, 2011.

YANG, L.; BERNSTEIN, J. B. Failure rate estimation of known failure mechanisms of electronic packages. Microelectronics and Reliability, v. 49, n. 12, p. 1563$1572,2009$.

YI, T. P. et al. Reducing electronic component losses in lean electronics assembly with Six Sigma approach. International Journal of Lean Six Sigma, v. 3, n. 3, p. 206-230, 2012. 